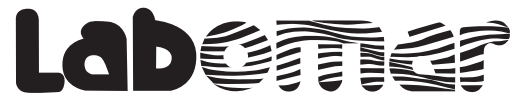

Arquivos de Ciências do Mar

\section{OCCURRENCE OF THE THREE SPOT GOURAMI TrichopoduS trichopterUS (ACTINOPTERYGII: OSPHRONEMIDAE) IN GUANABARA BAY, SOUTHEASTERN BRAZIL}

\section{Ocorrência de tricogaster Trichopodus trichopterus (Actinopterygii: osphronemidae) na Baía de Guanabara, área sudeste do Brasil}

\author{
Mauro José Cavalcanti' ${ }^{1}$, Paulo Roberto Duarte Lopes ${ }^{2}$ \\ 1 Ecoinformatics Studio, P.O. Box 46521, Rio de Janeiro - Brazil, 20551-970. \\ ${ }^{2}$ Prof. Assistente. Universidade Estadual de Feira de Santana - Departamento de Ciências Biológicas \\ (Museu de Zoologia - Divisão de Peixes), Avenida Transnordestina, s/no. (km 03 - BR-116), \\ Feira de Santana - Bahia, Brasil, 44036-900. E-mail: andarilho40@gmail.com
}

\begin{abstract}
The Spot gourami Trichopodus trichopterus is recorded for the first time in mangrove environments from Porto do Rosa, São Gonçalo $\left(22^{\circ} 47^{\prime} S-43^{\circ} 02\right.$ W), eastern Guanabara Bay, Rio de Janeiro state, Brazil. The species is seemingly established in the area, where it may have been introduced by aquarium trade activities. The potential environmental impacts of this introduction to the local ecosystem, already under stress by pollution and habitat destruction, are discussed.
\end{abstract}

Key words: ornamental species, aquarium, mangroves.

\section{RESUMO}

A presença de Trichopodus trichopterus é registrada pela primeira vez habitando em manguezais na localidade de Porto do Rosa, município de São Gonçalo $\left(22^{\circ} 47^{\prime} \mathrm{S}-43^{\circ} 02^{`} \mathrm{~W}\right)$, lado oriental da Baía de Guanabara, estado do Rio de Janeiro, Brasil. A espécie está aparentemente estabelecida na área, onde pode ter sido introduzida por atividades de aquariofilia. Os potenciais impactos ambientais desta introdução no ecossistema local, já sob estresse pela poluição e destruição de habitats, são discutidos.

Palavras-chave: espécie ornamental, comércio de aquarismo, Trichopodus trichopterus, manguezais. 


\section{INTRODUCTION}

The three spot gourami Trichopodus trichopterus (Pallas, 1770) is one of the four valid species of Osphronemidae and was previously included in the genus Trichogaster Lacepède, 1801 (Töpfer \& Schindler, 2009). The species is native from the Mekong River basin in southeastern Asia (Cambodja, Laos, Thailand, Vietnam), southern China (Yunnan), Malaysia, Borneo, Java, and Sumatra (Low \& Lim, 2012), where it inhabits mangroves, marshes, paddy fields, and other waterlogged areas. Because of its beauty and rustic habits, it is a very appreciated ornamental species. This, include Brazil, where the three spot gouramit is a popular species in aquarium trade.

The three spot gourami T. trichopterus has been introduced and became established in several parts of the tropics. The species has been recorded in United States (Florida) (Courtenay et al., 1984), Dominican Republic (Lever, 1996), Colombia (Welcomme, 1988), Jamaica (Geheber et al., 2005), Namibia (FAO, 2012), Reunion (Keith, 2002), India (Daniels \& Rajagopal, 2004), Sri Lanka (Pethiyagoda, 1990), Taiwan (Liao \& Liu, 1989), Philippines (Juliano et al., 1989), Papua New Guinea (West \& Glucksman, 1967; Allen, 1991), New Caledonia (Firmat \& Alibert, 2011), and Australia (Queensland) (Webb, 2003). In Brazil, it has been recorded in a man-made lake in Paraíba do Sul River basin, state of Minas Gerais (Magalhães et al., 2002).

In the present study, $T$. trichopterus was recorded for the first time in a natural environment, inhabiting mangroves on the east side of Guanabara Bay, state of Rio de Janeiro, southeastern Brazil.

\section{MATERIALS AND METHODS}

Four specimens of T. trichopterus (Figure 1) were collected on October, 28th, 2008 in a mangrove swamp (Figure 2) at the locality of Porto do Rosa, São Gonçalo $\left(22^{\circ} 47^{\prime} \mathrm{S}\right.$ $43^{\circ} 02^{\prime} \mathrm{W}$ ), on the east side of Guanabara Bay, Rio de Janeiro state, southeastern Brazil (Figure 3); a voucher specimen was deposited in the collection of Museu de Zoologia (Divisão de Peixes) da Universidade Estadual de Feira de Santana (state of Bahia, Brazil), preserved in alcohol 70\%, registered under the number MZUEFS 14274 (Figure 4).

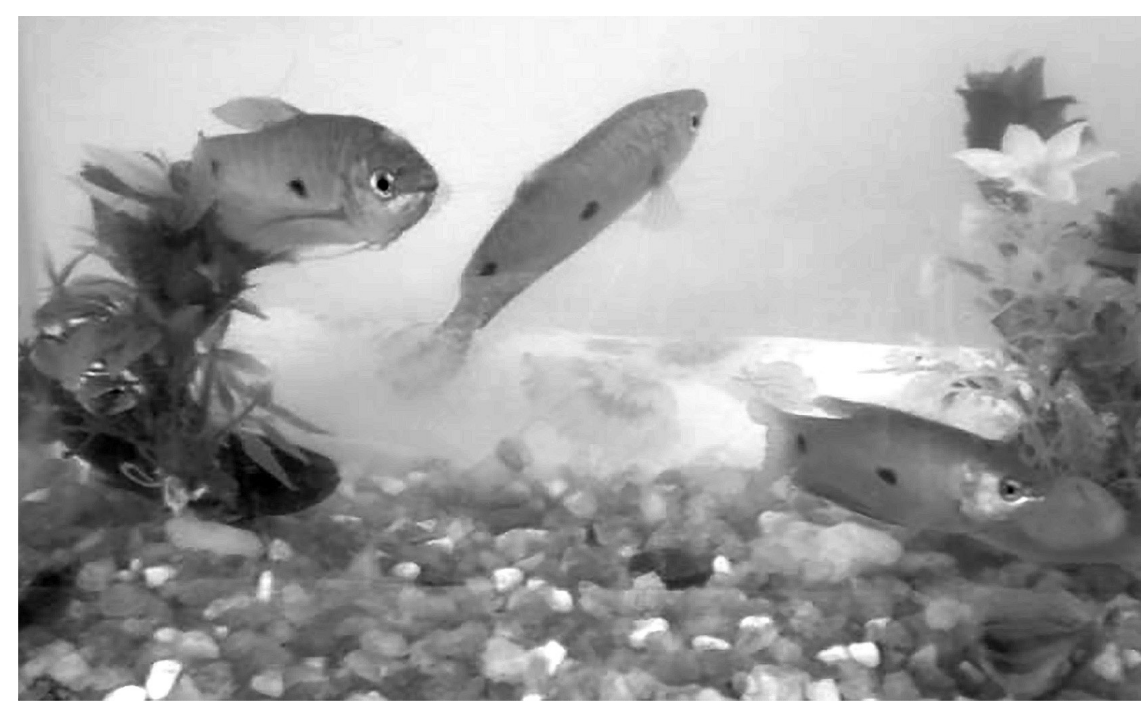

Figure 1 - Specimens of Trichopodus trichopterus collected in a mangrove swamp near the locality of Porto do Rosa, Guanabara Bay, São Gonçalo-RJ, Southeastern Brazil.

Photo by A. C. Barbirato. 


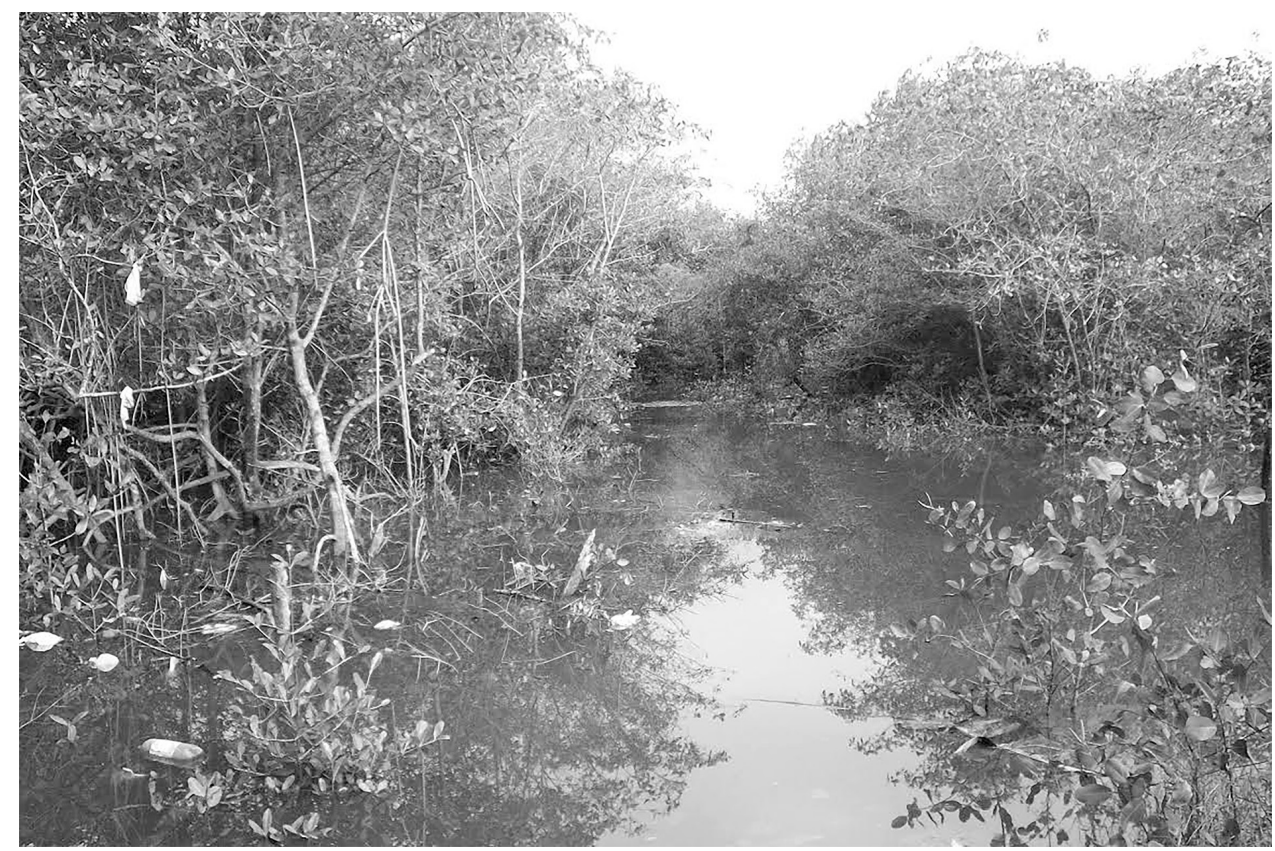

Figure 2 - Mangrove swamp where the specimens of Trichopodus trichopterus were collected. Photo by A.C. Barbirato.

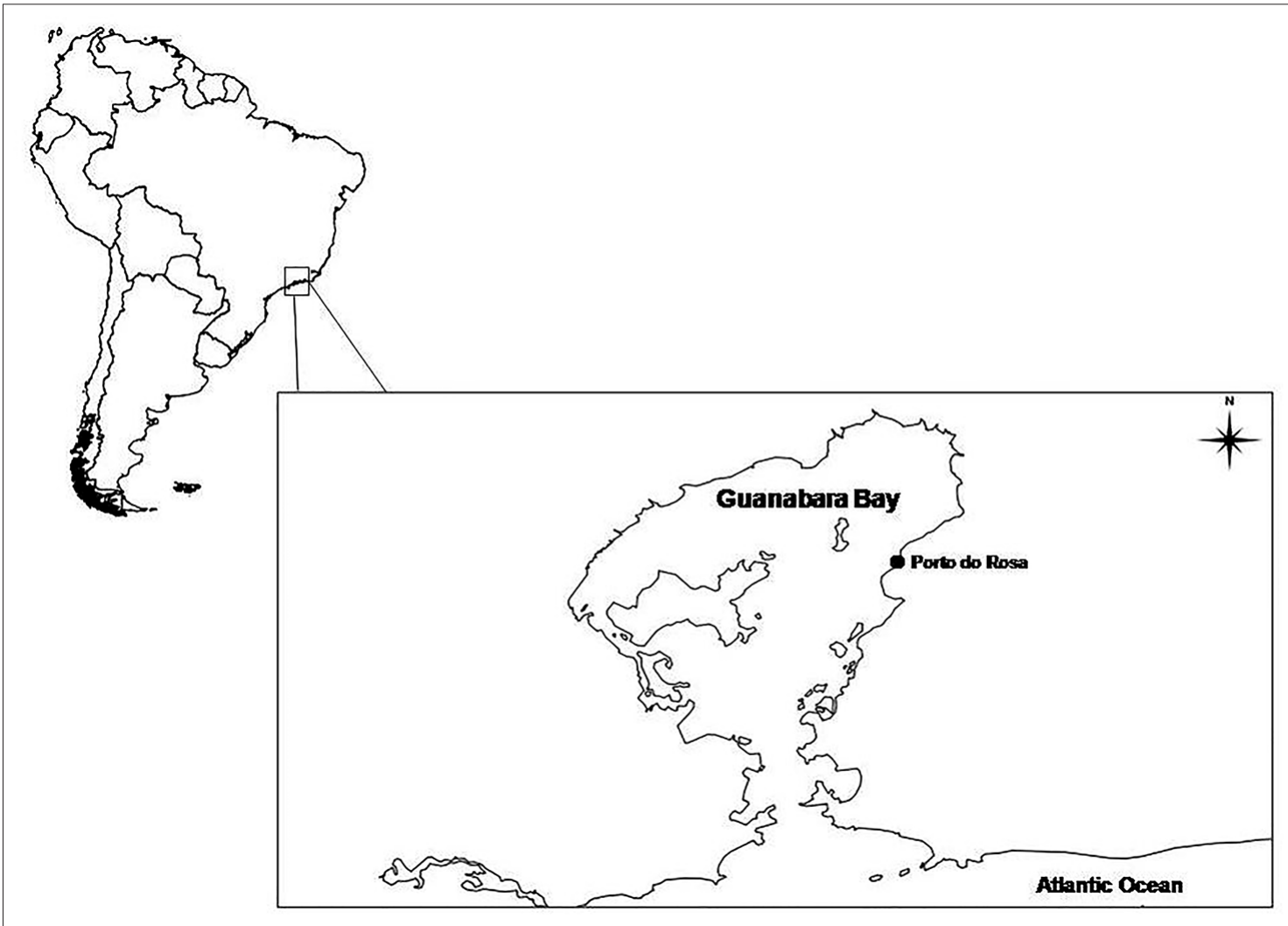

Figure 3 - map of the collection locality of Trichopodus trichopterus. 


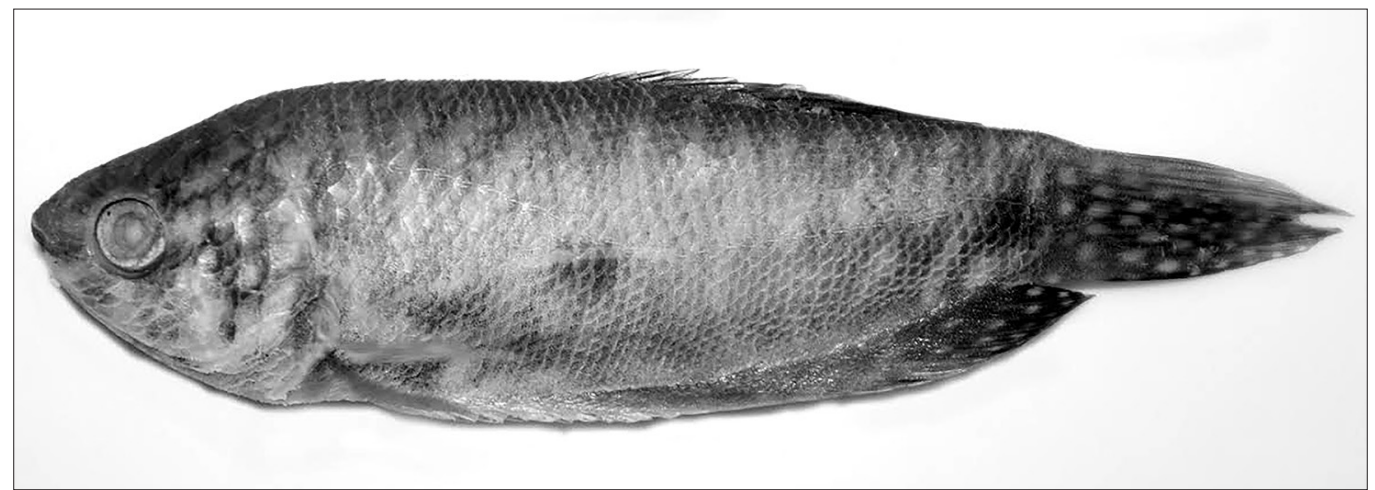

Figure 4 - Adult specimen of Trichopodus trichopterus (LIUEFS 14274) collected in Guanabara Bay, October 2008. Photo by J.T. de Oliveira-Silva.

\section{RESULTS}

Diagnosis: elongated body, more compressed posteriorly; eyes well-developed; small mouth in terminal position; lateral line beginning high but descending and becoming straight below the dorsal fin spines; dorsal fin approximately in the middle of the body, the part with spines united to the part with rays; anal fin longer than the dorsal fin and originating anteriorly to that; pelvic fins originating anteriorly to the pectoral fins; 10 rays in pectoral fins, the left one partially damaged; 3 rays in pelvic fins, one of them elongated in a filament, with that of the right side surpassing the anal fin; dorsal fin with 7 spines and 7 rays; anal fin with 12 spines and 36 rays; caudal fin with 16 rays; about 36 scales in lateral line, on each side of the body.

Coloration (in alcohol 70\%): Background color light, head and body with dark diagonal stripes with rounded light spots inside those, 2 dark spots present in body, the first below the lateral line, at the start of its straight part, and the other at the of caudal peduncle, pectoral and pelvic fins hyaline, dorsal and anal fins darker posteriorly and with rounded light spots, caudal fin darker medially and with light spots, as the body.

Body measurements (taken from the right side of the body with calipers to the nearest $0.05 \mathrm{~mm}$ ): standard length: $71.4 \mathrm{~mm}$, body depth: $22.9 \mathrm{~mm}$, head length: $21.3 \mathrm{~mm}$, snout length: $4.0 \mathrm{~mm}$, orbital diameter: $6.1 \mathrm{~mm}$.

\section{DISCUSSION}

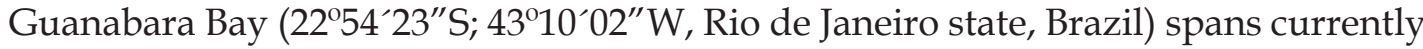
an area of about $380 \mathrm{~km}^{2}$ (from $468 \mathrm{~km}^{2}$ in 1500, after Amador, 1997) but has been reduced in $29.1 \%$ (Amador, 1997) of its original extension by successive landfills. Guanabara Bay possesses a contributing hydrographic basin of $4000 \mathrm{~km}^{2}$ and, despite its historical, economic, cultural, scientific, social, and environmental importance; it is one of the most degraded coastal environments in Brazil, both from the ecological and social aspects. It comprised a diversified complex of ecosystems that were gradually destroyed by disordered human occupation since the beginnings of the Brazilian colonization in the XVI century and continues being the subject of environmental aggressions. Currently, close to one million people live along its margins exerting, usually precariously, several activities that generate social, economic, and environmental impacts (Amador, 1997; Coelho, 2007). 
The ichthyofauna of Guanabara Bay has not yet been properly surveyed (Bizerril \& Costa, 2001). Matos \& Muratori (2001) report 125 fish species in the Bay area. In Brazil, there are already other records of biological invasions by fishes, both in marine and freshwater environments as, for example, tilapias (Cichlidae) (Lopes, 1989), Omobranchus punctatus (Valenciennes, 1836) (Blenniidae) (Mendonça et al., 2005, Gerhardinger et al., 2006) and Clarias galerpinus (Burchelli, 1822) (Clariidae) (Rabelo, 2009). This paper reports the first record of T. trichopterus in natural environment in Brazil. According to Bizerril \& Costa (2001), there are no records of other exotic fish species in Guanabara Bay.

In the area where it was collected, T. trichopterus is frequent in mangroves and waterlogged areas where it is apparently established. According to information provided by the local population, the introduction of this species occurred probably in relation to activities of ornamental fish trade. The environmental impacts of this introduction are so far unknown.

However, it is of concern that Patil et al. (2011) isolated from diseased T. trichopterus in India two antibiotic-resistant strains of Aeromonas spp. - bacteria occurring in freshwater and estuarine aquatic environments and known to cause infections in fishes and humans, including potentially severe gastroenteritis and wound infections (Ghenghesh et al., 2008; Janda \& Abbot, 2010; Parker \& Shaw, 2011). This raises concerns regarding potential risks to public health and poses an additional threat to the already stressed environment of the Guanabara Bay.

Acknowledgements - We express our thanks to Carlos Alberto Barbirato and Isac Barbirato, the fishermen who collected, donated, and provided information on the occurrence of $T$. trichopterus in Guanabara Bay. We also thank Angela Cristina Barbirato and Jailza Tavares de Oliveira-Silva (Univ. Est. de Feira de Santana), Dep. de Ciências Biológicas (Museu de Zoologia, Div. de Peixes) for taking photos of the living and preserved specimen. Univ. Est. de Feira de Santana supports the housing of a specimen of T. trichopterus in its scientific ichthyological collection.

\section{REFERENCES}

Allen, G.R. Field guide to the freshwater fishes of New Guinea. Christensen Research Institute, 268 p., Madang, 1991.

Amador, E.S. Baía de Guanabara e ecossistemas periféricos; homem e natureza. Edição do autor, 539 p., Rio de Janeiro, 1997.

Bizerril, C.R.S.F. \& Costa, P.A.S.C. Peixes marinhos do estado do Rio de Janeiro. Fundação de Estudos do Mar, 233 p., Rio de Janeiro, 2001.

Coelho, V. Baía de Guanabara: uma história de agressão ambiental. Casa da Palavra, 278 p., Rio de Janeiro, 2007.

Courtenay Jr., W.R.; Hensley, D.A.; Taylor, J.N. \& McCann, J.A. Distribution of exotic fishes in the continental United States, p. 41-77, in Courtenay Jr., W.R. \& Stauffer Jr., J.R. (eds.), Distribution, biology and management of exotic fishes. Johns Hopkins University Press, 448 p., Baltimore, 1984.

Courtenay Jr., W.R. \& Stauffer Jr., J.R. The introduced fish problem and the aquarium fish industry. J. World Aquacult. Soc., v. 21, p. 145-159, 1990. 
Daniels, R.J.R. \& Rajagopal, B. Fishes of Chembarampakkam Lake - a wetland in the outskirts of Chennai. Zoos' Print J., v. 19, p. 1481-1483.

Deacon, A.E.; Ramnarine, I.W. \& Magurran, A.E. How reproductive ecology contributes to the spread of a globally invasive fish. PLoS ONE, v. 6, n. 9, p. e24416, 2011.

Duggan, I.C.; Rixon, C.A.M. \& Maclsaac. H.J. Popularity and propagule pressure: determinants of introduction and establishment of aquarium fish. Biol. Invasions, v. 8, p. 377-382.

FAO. FAO Database on Introductions of Aquatic Species. http://www.fao.org/fishery/ introsp/2709/en, 2012.

Firmat, C. \& Alibert, P. One more alien freshwater fish species in New Caledonia: the three-spot gourami Trichogaster trichopterus (Teleostei: Osphronemidae). Belg. J. Zool., v. 141, p. 90-92, 2011.

Geheber, A.D.; McMahan, C.D. \& Piller, K.R. First record of the non-native three spot gourami, Trichogaster trichopterus (Pallas 1770) (Teleostei: Osphronemidae) in Jamaica. Aquat. Invasions, v. 5, p. S13-S16, 2010.

Gerhardinger, L.C.; Freitas, M.O.; Andrade, A.B. \& Rangel, C.A. Omobranchus punctatus (Teleostei: Blenniidae), an exotic blenny in the Southwestern Atlantic. Biol. Invasions, v. 8, p. 941-946, 2006.

Ghenghesh, K.S.; Ahmed, S.F.; El-Khalek, R.A.; Al-Gendy, A. \& Klena, J. Aeromonasassociated infections in developing countries. J. Infect. Develop. Countr., v. 2, p. 81-98, 2008.

Janda, J.M. \& Abbot, S.L. The genus Aeromonas: taxonomy, pathogenicity, and infection. Clin. Microbiol. Rev., v. 23, p. 35-73, 2010.

Juliano, R.O.; Guerrero III, R. \& Ronquillo, I. The introduction of exotic aquatic species in the Philippines, pp. 83-90, in de Silva, S.S. (ed.), Exotic aquatic organisms in Asia, in Proceedings of the Workshop on Introduction of Exotic Aquatic Organisms in Asia. 154 p. Fish. Soc. Spec. Publ. 3, Asian Fisheries Society, Manila, Philippines, 1989.

Liao, L.C. \& Liu, H.C. Exotic aquatic species in Taiwan, pp.101-118, in: de Silva, S.S. (ed.), Exotic aquatic organisms in Asia. Asian Fisheries Society, Darwin, Australia, 154 p., 1989.

Keith, P. Freshwater fish and decapod crustacean populations on Réunion Island, with an assessment of species introductions. Bull. Fr. Pêche Piscic., v.364, p.97-107, 2002.

Lopes, P.R.D. Tilápias em águas interiores no Brasil. Bol. Inform., Sociedade Brasileira de Ictiologia 17: 10-11, 1989.

Low, B.W. \& Lim, K.K.P. Gouramies of the genus Trichopodus in Singapore (Actinopterygii: Perciformes: Osphronemidae). Nature in Singapore, v.5, p.83-93, 2012.

Magalhães, A.L.B.; Amaral, I.B.; Ratton, T.F. \& Brito, M.F.G. Ornamental exotic fishes in the Gloria Reservoir and Boa Vista Stream, Paraiba do Sul River Basin, State of Minais Gerais, southeastern Brazil. Comun. Mus. Ciênc. Tecnol. PUCRS Sér. Zool., v.15, p.265-278, 2002.

Magalhães, A.L.B. \& Jacobi, C.M. E-commerce of freshwater aquarium fishes: potential disseminator of exotic species in Brazil. Acta Scient., Biol. Sci., v.32, p.243-248, 2010.

Mendonça, H.S.; Nunan, G.W.; Santos, S.R.; Bandeira, W.D. \& Santos, A.C. 2005 Ocorrência de Omobranchus punctatus (Valenciennes, 1836) (Teleostei, Blennidae) na Baía de Todos os Santos, Bahia: primeiro registro da invasão de uma espécie exótica de peixe marinho em águas brasileiras, p.69, in Resumos XVI Encontro Brasileiro de Ictiologia, João Pessoa, 2005. 
Nelson, J.S. Fishes of the world. $4^{\text {th }}$ ed. John Wiley \& Sons, 601 p., New Jersey, 2006.

Padilla, D. \& Williams, S. Beyond ballast water: aquarium and ornamental trades as source of invasive species in aquatic ecosystems. Front. Ecol. Environ., v.2, p.131-138, 2004.

Parker, J.L. \& Shaw, J.G. Aeromonas spp. clinical microbiology and disease. J. Infect., v.62, p.109-118, 2011.

Patil, R.C.; Upadhye, M.V.; Kolatkar, V.D.; Katchi, V.I., Kulkarni, G.J. \& Shouche, Y.S. Isolation and identification of two new strains of Aeromonas spp. from diseased gourami fish and aquarium water. Intern. J. Life Sci., v.5, p.25-31, 2011.

Pethiyagoda, R. Freshwater fishes of Sri Lanka. Wildlife Heritage Trust. 362 p., Colombo, 1990.

Rabelo, L.B. Alimentação e impactos da espécie exótica bagre-africano (Clarias gariepinus Burchelli, 1822) no estuário do rio Itanhém, Bahia. Dissertação de mestrado. Instituto Oceanográfico da Universidade de São Paulo. 79 p., São Paulo, 2009.

Strecker, A.L.; Campbell, P.M. \& Olden, J.D. The aquarium trade as an invasion pathway in the Pacific Northwest. Fisheries, v.36, p.74-85, 2011.

Töpfer, J. \& Schindler, I. On the type species of Trichopodus (Teleostei: Perciformes: Osphronemidae). Vertebrate Zool. v.59, p.49-51, 2009.

Welcomme, R.L. Register of International Introductions of Inland Aquatic Species. Food and Agriculture Organization of the United Nations, 328 p., Rome, 1988.

West, G.J. \& Glucksman, J. Introduction and distribution of exotic fish in Papua New Guinea. Papua New Guinea Agr. J., v.27, p.19-48, 1967. 
